\title{
POLISTES GALLICUS IN MASSACHUSETTS (HYMENOPTERA: VESPIDAE)*
}

\author{
By Mary A. Hathaway \\ Museum of Comparative Zoology, \\ Harvard University \\ Cambridge, Massachusetts 02138 USA
}

\section{INTRODUCTION}

Polistes gallicus (Linnaeus), a common and widespread paper wasp in the palearctic region, has been introduced into the United States in the Boston, Massachusets, area. During 1981 specimens were collected in Cambridge, Somerville, Belmont, and Newton, Massachusetts. P. gallicus was also collected in Cambridge in 1980, but was not seen in Belmont that year (R. J. McGinley, personal communication). Species identification was verified by Dr. Arnold S. Menke of the Systematic Entomology Laboratory of the United States Department of Agriculture. Presumably P. gallicus was only recently introduced; otherwise it would surely have been reported before this. It is a brightly colored and conspicuous wasp.

The purpose of this paper is to report the introduction of Polistes gallicus. The biology of the species in the Old World is reviewed briefly, and some observations of the wasp in Massachusetts are reported. Information on how to recognize $P$. gallicus is also included.

\section{Biology of Polistes GaLLICUS (LINNAEUS)}

Polistes gallicus is ubiquitous in the palearctic region, especially in the south. It is the most common Polistes in Spain (Giner Marí, 1945). The species' range extends north to Paris, but gallicus becomes rare in far northern France. It exists in warmer parts of Belgium and Germany, but does not occur in England, Denmark, or Scandinavia (Guiglia, 1972). Spradbury (1973) states that occasionally Polistes are introduced into the British Isles, but for some reason the genus is not able to sustain itself there. To the south, the range of $P$. gallicus includes northern Africa, where the species is known from desert oases (Richards, 1953), and extends east through Israel and Iran. In Asia P. gallicus has been collected in southern

\footnotetext{
*Manuscript received by the editor September 29, 1981.
} 
U.S.S.R. and throughout China, east to the Pacific coast (Guiglia, 1972; Yoshikawa, 1962). Generally, the species is found in warmer and dryer localities within its range. It is not common above $1000 \mathrm{~m}$ elevation, although in southern Spain specimens have been collected above $2000 \mathrm{~m}$ (Guiglia, 1972).

The biology of $P$. gallicus varies considerably between the climatic extremes of the area it inhabits. North of the Alps, nests are built in enclosed places, such as metal containers and gutter pipes. This type of nest has also been reported by Pardi from the coast of Tuscany in Italy (Guiglia, 1972, and references therein). Throughout most of Italy, however, the nests of $P$. gallicus are built in the open, and typically hang from eaves, branches, or other protective horizontal structures. The nest hangs from a slender peduncle with its disc oriented horizontally, and the cells opening downward. Often there are several accessory peduncles. Infrequently, nests are found whose discs are oriented vertically.

In Italy, where the species has been studied extensively, nests of close to 500 cells have been reported on several occasions (Guiglia, 1972). It is apparently common for colonies of this species to become quite large in the south.

Polistes gallicus colonies are haplometrotic (with a single foundress) in northern Germany and presumably throughout the northern extent of the species' range. Further south, for instance in southern Germany, pleiometrotic colonies (with several foundresses) are occasionally reported (Richards, 1953). In Italy the species is typically pleiometrotic, although as with the pleiometrotic colonies reported from Germany, one queen is clearly dominant and lays most of the eggs. The subordinate, or accessory females function as workers in the nest. According to Pardi (1948), after the first workers emerge the accessory females are chased off the nest or killed by the queen. This situation resembles nest founding in $P$. fuscatus (Fabricius), the common paper wasp in northeastern United States, except that in P. fuscatus subordinate females are usually allowed to remain on the nest after workers have emerged (West, 1967). In Africa $P$. gallicus colonies reproduce by swarming, with a reproductive female leaving her nest in the company of several workers (Richards, 1953).

\section{Local Observations}

I report here on 2 nests of $P$. gallicus in Cambridge, Massachu- 
setts. Both were in enclosed situations, similar to those described as typical in the northern parts of the species' range in Europe. The first nest was located inside a metal pole supporting a stop sign. The pole was $71 / 2 \mathrm{~cm}$ in diameter, and open at the top. The single peduncle of this nest was located $28 \mathrm{~cm}$ from the top of the pole. The nest was suspended from the pole's side and faced north. This nest contained 134 cells, and measured $8 \mathrm{~cm}$ high and $5 \mathrm{~cm}$ across.

A second nest was located inside an open vertical pipe, $35 \mathrm{~cm}$ tall and $8 \mathrm{~cm}$ in diameter. The nest was suspended from the side of the pipe and faced west-north-west. Its peduncle was located $6 \mathrm{~cm}$ from the top of the pipe. This nest contained 153 cells and also measured $8 \mathrm{~cm} \times 5 \mathrm{~cm}$.

$P$. gallicus does not seem to be an aggressive species. I have been able to observe a nest from as close as $15 \mathrm{~cm}$, apparently without disturbing the wasps.

The prognosis for permanent establishment of $P$. gallicus in the western hemisphere appears good. The species seems quite able to withstand the climate in the northeast. 1980-1981 was an unusually cold year in Boston, with 5,819 degree days accumulated between June 1 and May 30, as opposed to the 30-year normal of 5,597 (United States National Weather Service statistics, telephone information).

\section{ReCognition of Polistes GaLLICUS}

In northeastern United States $P$. gallicus would more likely be confused with a yellow jacket (Vespula spp.) than with another paper wasp. Although its shape and flight are similar to the native Polistes', it is relatively small and its markings and coloring are strikingly different. P. gallicus is black with bright yellow maculations (see figure 1).

Specimens collected in Massachusetts have varied considerably in their markings, with some showing more yellow than others, especially on the clypeus. This has also been true of specimens collected from the same nest. $P$. gallicus is known to be quite variable in Europe (Guiglia, 1972).

Males have completely yellow faces and their antennae are curled at the tips, a characteristic common in the genus. Their antennae are quite short, however, compared to males of other species. In other superficial respects, males of $P$. gallicus resemble the females. 


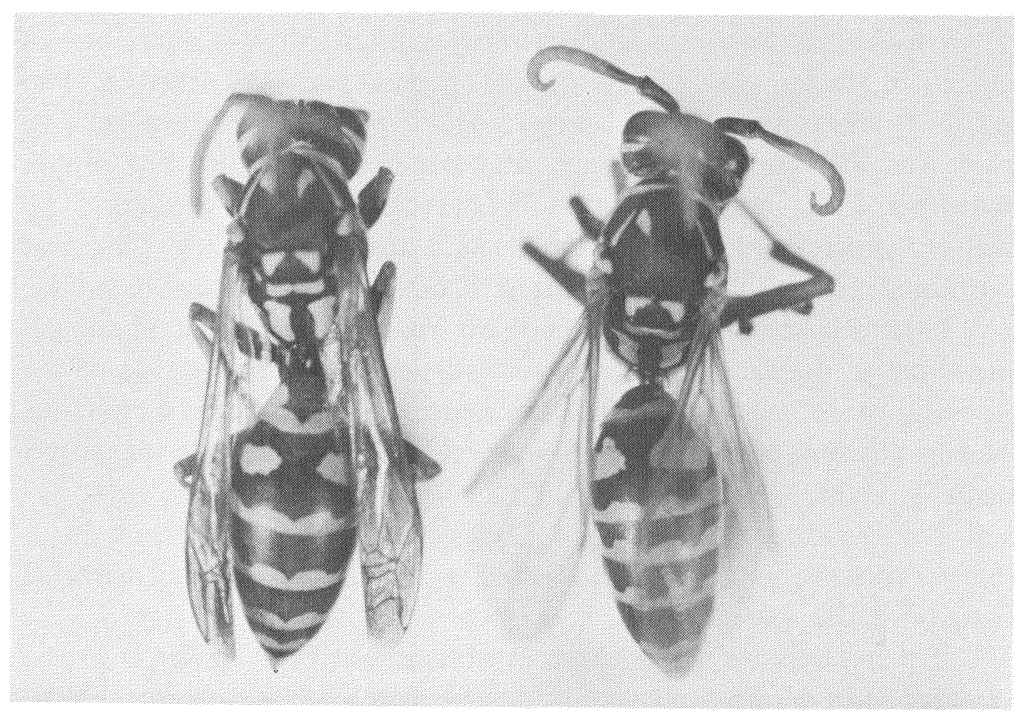

Figure 1. Polistes gallicus worker (left) and male (right) collected in Cambridge, Massachusetts. Length of worker, $1.4 \mathrm{~cm}$.

\section{ACKNOWLEDGEMENTS}

I wish to thank Dr. Howard E. Evans and Dr. Ronald J. McGinley for their helpful comments on the manuscript, Dr. Frank M. Carpenter for photographing the specimens, and Dr. Arnold S. Menke for the species identification. I also wish to thank Mr. Loren Preston of the Cambridge Department of Traffic and Parking, for the loan of a stop sign pole, and Mrs. Rita Kelley for permission to work on her property.

\section{REFERENCES}

Giner Mari, J.

1945. Himenópteros de España, fams. Vespidae, Eumenidae, Masaridae, Sapygidae, Scoliidae, y Thynnidae. Madrid: Instituto Español de Entomología. $142 \mathrm{pp}$.

Guiglia, Delfa

1972. Les Guêpes Sociales d'Europe Occidentale et Septentrionale. Faune de l'Europe et du Bassin Mediterranean, VI. Paris: Masson et Cie. $181 \mathrm{pp}$.

PARDI, L.

1948. Dominance order in Polistes wasps. Physiol. Zool. 21(1): 1-13. 
RICHARDS, O. W.

1953. The social insects. London: Macdonald and Co. 219 pp.

Spradbury, J. Philip

1973. Wasps: an account of the biology and natural history of solitary and social wasps. Seattle: University of Washington Press. 408 pp.

West, MARY JANE

1967. Foundress associations in polistine wasps: dominance hierarchies and the evolution of social behavior. Science 157: 1584-1585.

YoshiKawa, Kimio

1962. Introductory studies on the life economy of polistine wasps, VI: geographical distribution and its ecological significances. J. Biol. Osaka City University 14: 19-43. 

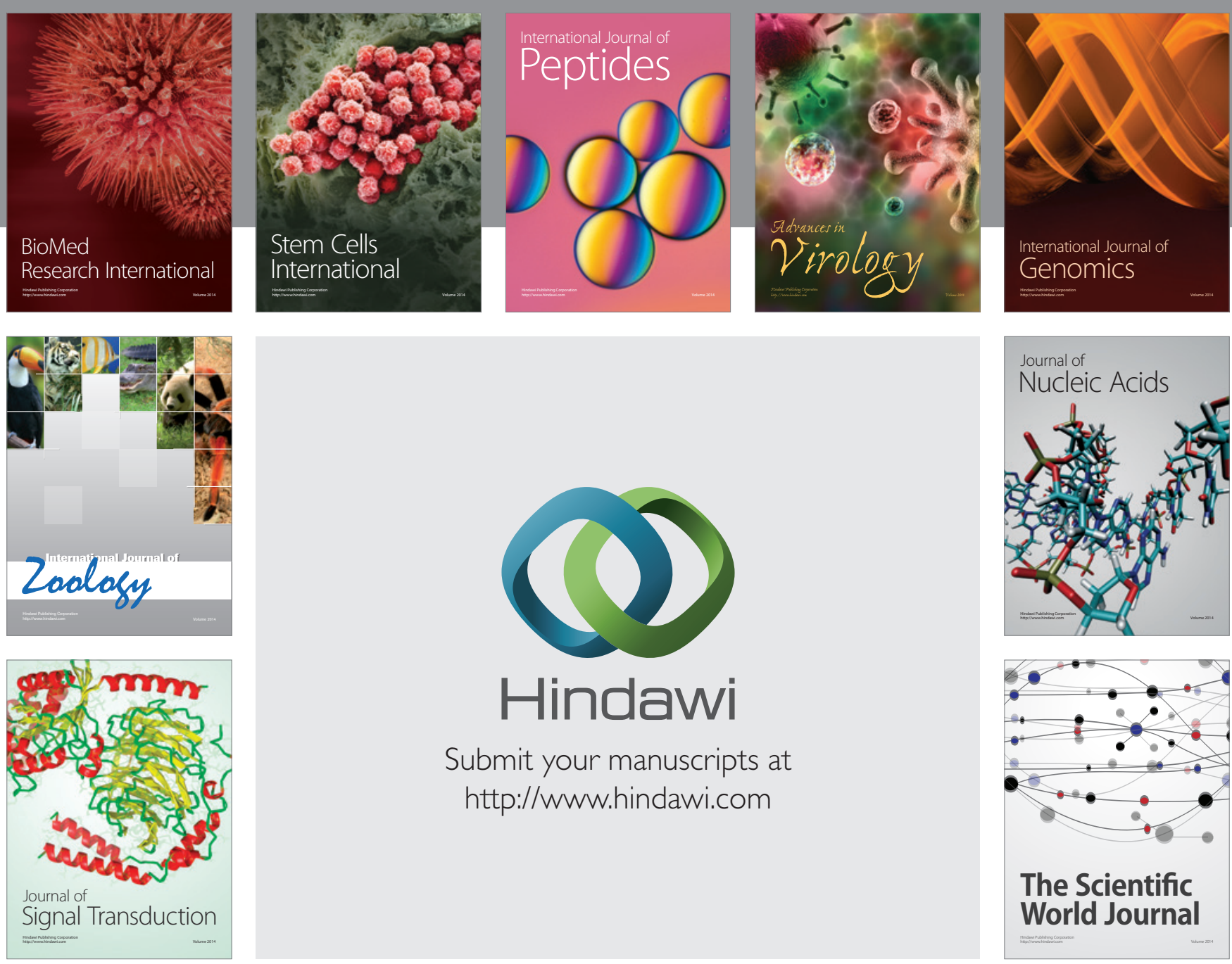

Submit your manuscripts at

http://www.hindawi.com
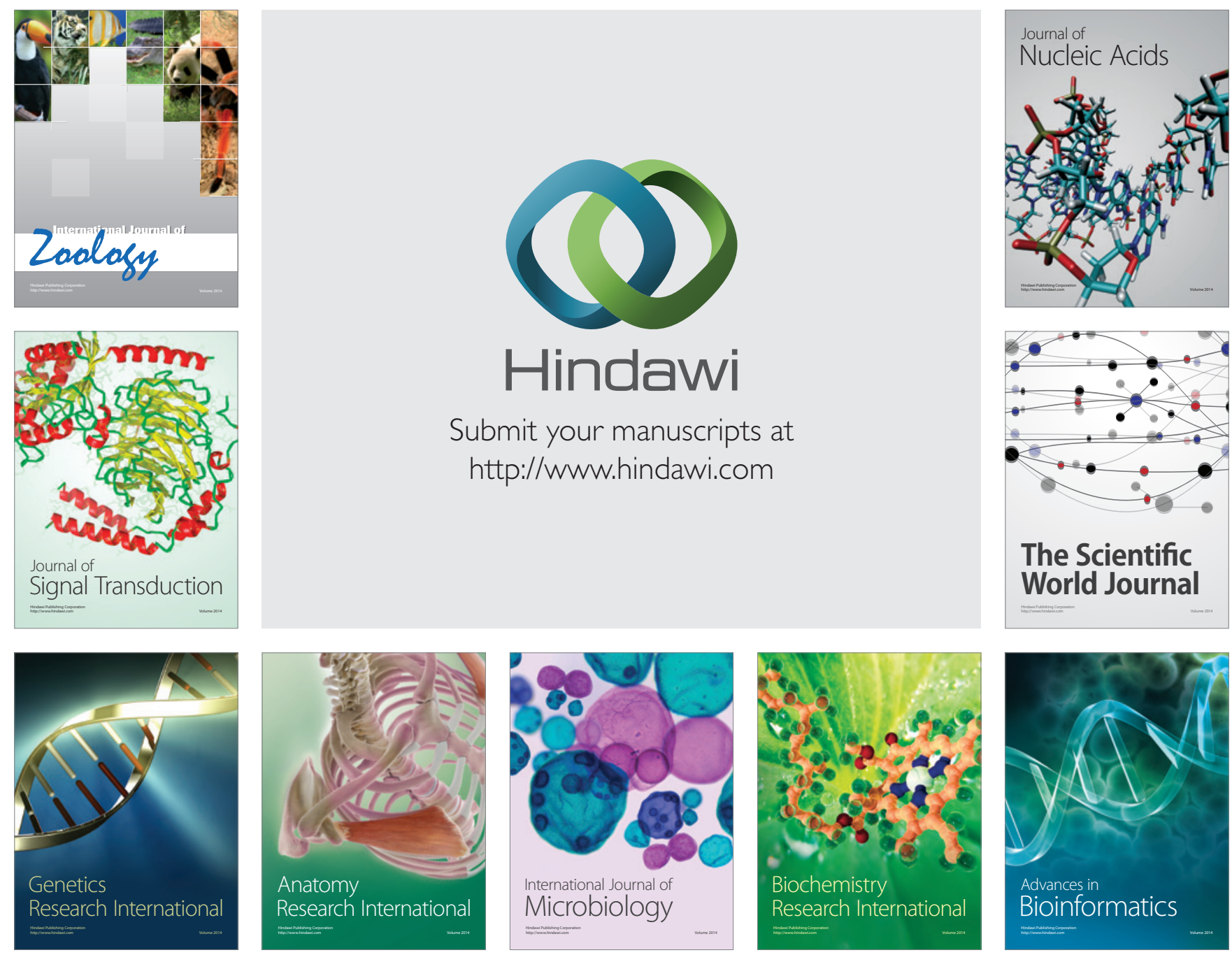

The Scientific World Journal
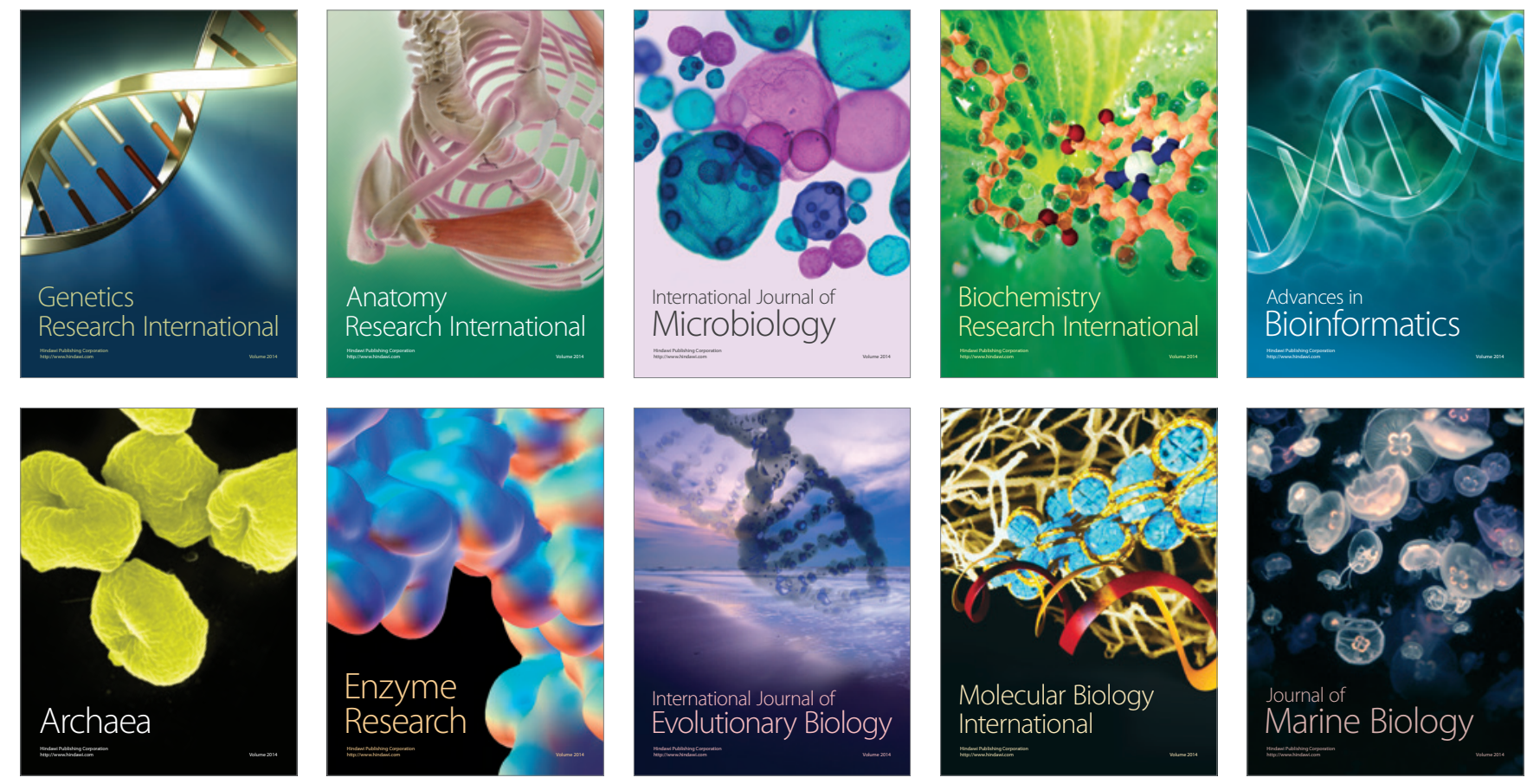